\title{
A Research Project for Evaluating the Competitivity of International MICE Industry in Taiwan
}

\author{
I-Ying Chang \\ Department of Tourism and MICE, \\ Chung Hua University, Taiwan, R.O.C. \\ Email: bomplady@gmail.com
}

\begin{abstract}
According to figures from Bureau of Foreign Trade, Ministry of Economic Affairs, ROC, the economic effect of MICE industry is roughly seven to ten times more than the direct incomes of the organizers', which means significant effectiveness. Taiwan, located in Asia, where the MICE industry is highly prosperous, should be a beneficiary of it. Nonetheless, surrounding countries like Mainland China and Thailand have large-scaled convention centers and relatively low expenses, yet Hong Kong and Singapore present full support to the convention industry, building close connections among convention, exhibition, and incentive traveling. For MICE industry in Taiwan, as traditional industries moving out and internal market shrinking down, along with being surrounded by strong competitors and difficulties in hosting large-scale international, professional events, such reasons have brought rigorous challenges to its development in international MICE industry. Therefore, it is the primary task now to reevaluate the competitivity of international MICE industry in Taiwan and to find a way for survival in the highly competitive market of MICE industry.
\end{abstract}

In this article, the Fuzzy Delphi Method was applied to the expert assessment of input and output factors for consensus through geometric averages. Medians of evaluation scores of input and output factors were used as criteria for screening out valid input and output factors to evaluate the performance of MICE industry. There are four predicted input-output variables. After strict screening, there are nine expected decision-making units (DMUs). Data Envelopment Analysis (DEA) is applied to evaluate the competitivity of international MICE industry in Taiwan and to discern effective factors in promotion and development of international MICE industry in Taiwan. The results are expected to improve the competitivity of international MICE industry in Taiwan.

Keyword - International MICE in Taiwan; industry competitivity; Data Envelopment Analysis

\section{INTRODUCTION}

The MICE industry involves a wide variety of related industries and brings great economic benefits. Therefore, many governments put emphasis on and promote heavily the MICE industry. The success of MICE industry is expected to promote local, social, and national economic profits and to hold onto the future trend of the industry. The MICE industry owns the feature of multiple integration, combining relevant service industries like trading, transportation, finance, touring, etc. It creates the multiplier effect by not only integrating production, processing, and manufacturing in secondary industry but also associating marketing, catering, and tourism in tertiary industry. Its characteristics fall in between manufacturing and service industries. Nonetheless, excessive convention centers would bring in strong competition fighting for event hosting privilege. According to figures from International Congress and Convention Association (ICCA), there are roughly four hundred thousand meetings and exhibitions worldwide annually, with a total spending of two hundred eighty billion US dollars. Estimates from Union des Foires Internationales (UFI) show that annual production of MICE industry has reached 1.2 trillion US dollars, in which four hundred billion comes from meetings and eight hundred billion from exhibitions (Chou \& Tsai, 2013). A report from Tourism Bureau, Ministry of Transportation and Communications, ROC (2014) pointed that there were more than eight million foreign visitors coming to Taiwan in 2013, with a foreign exchange income of more than three hundred sixty billion. Apparently, MICE industry activities can bring significant economic benefits to the host country and city (Po, 2010).

In terms of international trend, the development of MICE industry in Europe and the United States has come to a matured phase, and was influenced by the financial turmoil so that the scale of MICE industry and related investment has become more cautious and conservative. Comparatively, other emerging countries, with their fast growing economy as well as prospects of MICE industry and the promising economic benefits, have expanded the investment in MICE industry and therefore caused the gradual shift of MICE industry from the West to Asia (Zhang, 2010). The economic growth in Taiwan has longtime been driven by exports, and conferences and exhibitions have been important platforms for exchange of industrial information and marketing channels for companies' propagation of their products and services. By way of international meetings, it promotes international interaction and cooperation. Furthermore, international exhibitions 
help the companies acquire information and business opportunities rapidly and promote business activities and technology interactions, and lead to the upgrading and transformation of technology in relating industries.

This study focuses on international conferences and exhibitions, i.e., MICE activities, hosted in Taiwan and "Meet Taiwan", a government promotion project for development of MICE industry in Taiwan, trying to probe whether "Meet Taiwan" can really enhance the competitivity of MICE industry in Taiwan. There are three major objectives for this study: 1) Using Data Envelopment Analysis (DEA) for evaluating the management efficiency for international meetings and exhibitions hosted in Taiwan in 2017, as performance indicators for observing the development of MICE industry; 2) Using data from the "Meet Taiwan" website to check for the frequency, lengths, and scales of international MICE activities in Taiwan, and to see whether the selection of activity venue would influence the chance of hosting international MCE activities; 3) For places not for hosting MICE activities directly, like non-urban areas, would it be possible for them to enhance the competitivity of MICE industry in Taiwan by their special humanities and natural touring resources?

\section{LITERATURE REVIEW}

\section{A. MICE Industry}

The MICE industry, originating from European and North American markets, has a steady increasing number in host cities or touring destinations because of the attraction of highly profitable commercial MICE activities. As Europe and North America accommodate headquarters of many international associations and inter-governmental organizations, developing countries are not able to host commercial activities at the same level, neither are they able to provide the same class of market intelligence as Europe and North America (Boo $\&$ Kim, 2010). Since the 1980s, the sudden emergence of the Asia-Pacific area, surpassing the traditional market, reflected shift of the development in tourism. Due to the big economic benefits brought by MICE industry, many governments invested heavily in constructing convention centers, especially in poor areas (Cheng et al., 2010). The MICE industry grows rapidly in global markets, constructing or expanding at an amazing speed (Chiang et al., 2012). In additional to enhancement of the interior hardware and software facilities of convention centers, the trend of modern technology design is also emphasized. It is expected to earn more opportunities of hosting activities by highlighting the specialties of the convention centers via interior decoration, and to further boost the prosperity of local societies (Cheng et al., 2010). Meeting Professionals International (MPI) marks that meetings and exhibitions are in a field derived from M.I.C.E.: $M$ stands for Meetings, referring to seminars and training sessions held by enterprises or organizations; I for Incentive Tourism, concerning special touring experiences and gatherings for enhancements of achieving goals of the enterprises or organizations as well as rewards to the performance of workers; $\mathrm{C}$ for Conventions, referring to large meetings held by companies or organizations for fixed periods of time, in order to accomplish certain topics or targets; $\mathrm{E}$ for Exhibitions, regarding business practices for highlighting products, technologies, and operation outcomes of industrial development by shows and displays (Ekiz, 2011). Kim et al. (2010) named Conventions and Exhibitions industry (M.I.C.E.) as conventions and Exhibitions service industry, which is a tertiary industry providing services to primary and secondary industries, offering services of planning, organizing, administrating, and marketing for conventions and exhibitions. MICE industry, considered a chimneyless industry, is believed to be the most promising industry following finance and trading, and, along with real-estate and tourism industries, are also labeled as the three industries of new economy in the 21st century, featuring three highs and three Larges (three highs: high growth potential, high added values, and highly beneficial innovations; three larges: large output, large opportunities for employment, and large industry associations).

\section{B. Factors Affecting Competitivity of International MICE}

Government departments, for city image and local economic development, may offer incentives such as large funding, favorable conditions, relevant preferential policies, tax cuts, and low interest rates, etc. to promote construction of convention centers, and to facilitate fast development of local MICE and tourism industries (Lu, 2013). The convention centers would emphasize the innovative designs, and locate at the center of the city or near downtowns. Professional convention centers are usually equipped with apparatus for both conventions and exhibitions, of large and flexible space, service-oriented, offering diverse, highquality catering equipments, of comfortable and luxury facilities, stressing on user-friendliness, capable of hosting a variety of activities, and to provide organizers the latest technologies. Other than private investments, governments may also play an important role in the development of MICE industry. Patterns of government supports could be highly diverse, including attracting investment, cutting taxes, loaning, assisting training, and marketing activities (Maier, 2013). In short, the major impact of MICE industry onto macroeconomics presents the raise of employment rate and income. In addition, MICE tourism also brings other invisible benefits, e.g., social-cultural benefits, exchange of ideas, development of business public relations, offering venues for in-service education and training, convenience for technology transmission, etc.

According to Zhang et al. (2011), event organizers, when planning conventions or exhibitions, may consider the following factors for the selection of event venue: I) transportation convenience: cost, time, frequency, convenience, administrative barriers; II) local support: local branches, local bureau of convention and visitor o r, subsidies; III) external opportunities: entertainment, shopping, tourism, leisure, and business opportunities; IV) accommodation 
facilities: capacity, cost, service, safety, equipments; V) convention facilities: capacity, layout, price, environment, service, safety, equipments, experiences; VI) information: reputation, marketing; VII) site environment: climate, settings, infrastructure, hospitality; VIII) other criteria: risk, profit, association propagation, novelty, etc. Construction of critical infrastructure enhances the growth of needs of conventions and exhibitions (Ekiz, 2011). For conventions and exhibitions in Asia, the quality of facilities and services is good, the pricing is reasonable, and the technology and equipments are advanced. Furthermore, all the major sites for conventions and exhibitions are equipped with convenient and complete public transportation systems, along with modern international airports, offering service operated by major international airlines. Chiang at al. (2012) pointed out that many critical economic revolution policies, plans, and marketing projects in the AsianPacific area have compensated for the insufficiency of basic infrastructures. Therefore, this has caused the rapid growth of MICE industry in the Asian-Pacific area.

\section{Evaluation Factors of the Competitivity of MICE Industry Performance}

Cheng et al. (2010) adapted the four aspects for evaluating business performance: financial, customer, internal processes, and learning and growth; into four constructs for assessing hotel websites: technology, marketing, internal, and customer. Kaplan and Norton (2001) proposed KPIs for the four aspects for business concerns, yet Morrison et al. (2005) confirmed critical factors for success in each aspect, from the concerns of both hotel website operators and customers, and then appraised the websites of hotels via content analysis. Boo and Kim (2010) evaluated similarities and differences in traveling agencies between America and China via aspects of financial, customer, internal processes, as well as innovation and learning. Zhang et al. (2011) proposed four aspects: financial, customer, internal processes, innovation and learning; for assessment of integrated Internet service and competition strategies for business application. In each of the four aspects, strategies for evaluation of integrated Internet service were provided. The web service needs combination of business strategy and information technology strategy as well as wellplanned execution of Internet service to gain advantages in competition and to make profit for business. Lu (2013) evaluated ten convention centers in the US, applying Cheng et al. (2010)'s four aspects, and proposed critical factors of success for evaluation of convention centers. Lu (2013) applied the four aspects of technology, marketing, internal, and customer, adapted by Ekiz (2011) for evaluation of eight Korean convention centers, and assessed the performance by critical factors of success. In addition to using Lu's (2013) four aspects and critical factors for success as major assessment tools, this article also applied the ten criteria from the e-commerce evaluation principles for evaluation of convention center websites.

\section{RESEARCH METHODOLOGY}

\section{A. Efficiency Evaluation Analysis}

From perspective of economics, a business unit with less input and more output means better performance of this unit. For assessing such performance, "efficiency" could be used as a criterion for evaluation. By comparing input and output, efficiency could be defined as: Efficiency = weighted total output / weighted total input. A function relates any given set of input to the maximum obtainable output is called "production function". In general, the maximum output for a given input is less then the product of production function. Therefore, it is also called "production frontier". Efficiency, in geometric sense, is to project, with envelopment, all the inputs of the DMU for evaluation and its outputs to a space, in order to evaluate the relative efficiency of the organization, and to obtain an efficient envelope that envelops all the empirical data, to form the efficient frontier. Then calculating the distance from the value of individual DMU to the efficient envelope will produce the relative efficient level.

This study applies Data Envelopment Analysis (DEA) as evaluation tool for efficiency. It is not like conventional regression analysis, which finds an average path in a series of data points. Rather, it envelops data from all the samplings and tries to figure out the relationship. It has the necessary advantages for a good efficiency evaluation model. This method uses linear programming techniques to account for factors for performance evaluation for each DMU, and to make performance comparison among DMUs with similar features.

\section{B. Input-Output}

When applying DEA to evaluating the performance of MICE industry, it has to choose proper factors of input and output for efficient assessment of the management performance of each DMU. In order to include expert opinions in selecting input and output factors, to reduce cost involved, and to avoid ambiguity in the survey process, the Fuzzy Delphi Method is employed to screen out the input and output factors. This study plans to issue twenty-five copies of questionnaire. Fremont et al. (1970) pointed out that the consensus from more than five participants is accountable for further analysis. The experts interviewed in this study come from industry, government, and academia fields respectively, and all of them have frequent interaction with MICE industry, therefore should be considered representative.

In this study, after the Fuzzy Delphi Method operation, the geometric averages are utilized to obtain consensus among experts in evaluating input and output factors. Medians in assessment scores of each of the input and output factors are used as screening thresholds to get input and output factors for evaluating the performance in MICE industry. There are four anticipated input and output factors in this study, and a total of nine probable DMUs after strict screening. 
All the data of all the variables in this study are obtained from public accessible statements and annual reports.

\section{Definitions of variables \\ 1) Input Variables:}

a) Technology: including relevant facility costs, industry scale and level, business investment, transportation, hotels and restaurants, tourism resources.

b) Marketing: including partnership, related regulation system, experience of hosting MICEs, marketing and propagation, international visibility, etc.

c) Internal: including equipment readiness, capacity, personnel proficiency, etc.

2) Output Variables:

a) Customer: including number of event participants, length and scale of events, frequescy of events, etc.

b) Administration income: including total income of event sites, total income of catering, hotel occupancy rate, etc.

\section{ANTICIPATED RESULTS}

\section{A. Anticipated Works Completed}

- To perform competitivity evaluation of MICE industry by using DEA.

- To find out representatives of competitivity in MICE industry by integrating results of analysis.

- To integrate and interpret research outcomes and to offer suggestions.

\section{B. Anticipated Contributions}

- This study evaluates the competitivity of MICE industry in Taiwan, and figures out relevant factors affecting the propagation projects for development of international MICE industry in Taiwan. The outcome should be able to enhance the competitivity of international MICE industry in Taiwan.

- To further realize the current status of MICE industry in Taiwan, and to recognize the representatives of the most competitive strength of MICE industry in Taiwan. Furthermore, via the most competitive representative, to explore factors of the best competitivity and to enhance relevant professional knowledge. Altogether, it helps to improve research competence.

\section{Reference}

[1] Assaf, A., Barros, C. P., \&; Josiassen, A. (2010). Hotel efficiency: a bootstrapped metafrontier approach. International Journal of Hospitality Management, 29(3), 468-475.

[2] BO.Yun-Chang (2010). Develonment Straigv of MICE Industry. Taipei Economic Quarterly, (2).

[3] Boo, S., \&; Kim, S. (2010). The influence of convention center performance on hotel room nights. Journal of Travel Research, 49(3), 297309.

[4] Cheng, H., Lu, Y.C., \&; Chung, J.T (2010).Assurance region context-dependent DEA with an application to Taiwanese hotel industry. International Journal of Operational Research, 8(3), 292-312.

[5] Cheng, H., Lu, Y.C., \&; Chung, J.T. (2010).Improved slack-based context-dependent DEA - A study of international tourist hotels in Taiwan.Expert Systems with Applications, 37(9), 6452-6458.

[6] Chiang. C.C.. Chen. Y.C.. Huang. L.F..\&Hsueh. Chu. Yu-Ming. \& Tasi. Shiue-Yi. (2013). The Develonment of MICE and Evaluation of MICE Education in Taiwan. Yu Da Academic Journal, Vol.35, pp. 57-74.

[7] K.F.(2012).Destination Image and Marketing Strategy: An Investigation of MICE Travelers to Taiwan. Journal of American Academy of Business, 18(1),224-231.

[8] Ekiz, E.H.(2011).An Analysis of Conference Attendee Motivations: Case of International Conference Attendees in Singapore. Journal of Travel and Tourism Research, Spring 2011,50-64.

[9] Fremont, A., Jr. Shull, A. L. Delbecg and L. L. Curmings, 1970, Organizational Decision Making, McGraw-Hill, p.151.

[10] Kanlan. R. S.. \& Norton. D. P. (2001). The strategv-focused organization. Strategy and Leadership, 29(3), 41-42.

[11] Kim, S. S., Park, J. Y., \&; Lee, J. (2010).Predicted economic impact analysis of a mega-convention using multiplier effects. Journal of Convention \&; Event Tourism, 11(1), 42-61.

[12] Lu, K. H. (2013). Strategic group identification with the non-radial context-dependent DEA: the case of Taiwanese international tourist hotels. Storage Management Solutions. 5(4), 71-88.

[13] Maier, T. A., \&; Johnson, M. (2013).An empirical investigation into convention hotel demand and ADR trending. Journal of Convention \&; Event Tourism,14 (1), 2-20.

[14] Morrison. A. M.. Tavlor. J. S.. \& Douglas. A. (2005). Website evaluation in tourism and hosnitalitv: the art is not vet stated. Iournal of Travel \& Tourism Marketing, 17(2-3), 233-251.

[15] Tourism Bureau. (2014). http://taiwan.net.tw/.

[16] Zhang, Y., Qu, H., \&; Guo, Y. Z. (2011). A study of the agglomeration of China's convention industry: an economic and neoeconomic geography framework approach. Tourism Economics, 17(2), 305-319. 